\title{
Implementasi olah data tekanan udara ekstrim dari BMKG untuk meningkatkan hasil belajar siswa pada pokok bahasan tekanan Di SMP Negeri 4 kota Bengkulu
}

\author{
Ria Agustin ${ }^{1 *}$, M. Farid ${ }^{2}$, Nirwana ${ }^{3}$ \\ ${ }^{1}$ Pascasarjana Pendidikan IPA Universitas Bengkulu, Indonesia \\ ${ }^{2}$ Jurusan Fisika FMIPA Universitas Bengkulu, Indonesia \\ ${ }^{3}$ Pendidikan Fiska Universitas Bengkulu, Indonesia \\ "Email: riaagustin4624@gmail.com
}

DOI: $\underline{\text { https://doi.org/10.33369/pendipa.3.3.160-166 }}$

\begin{abstract}
[Implementation of Extreme Air Pressure Data Processing from BMKG to Improve Students Learning Outcomes on the Subject of Pressure in SMPN 4 Bengkulu City]. This Study aims to ;1) produce pressure simulations in the form of images as teaching materials on the concept of air pressure; 2) produce teaching materials in grapichal form so that they. This research is a quasi-experimental research based on purposive sampling technuque with the nonequivalent control group design. The sample in this study amounted to two classes, namely VIII.1 as a control class and VIII.2 as an experimental class with a total sample of 30 students in each class. the instrumen in thus study was in the form of objective testa of 10 questions with four answer choices. The results of the study show: 1) air pressure is influenced by temperature, altitude of place and the distribution of oceans and land. Highest air pressure of 1013,8 milibar, lowest air pressure of 1004,0 milibar and the average air pressure of 1008,6 milibar; 2) there are differences in learning outcomes between students taught with instructional materials of extreme air pressure data from BMKG with inquiry models with students taught with a discussion and assignment model shown by $t_{\text {hitung }}>t_{\text {tabel }}(7,63>2,01)$ with a significance level $5 \%$.
\end{abstract}

Keywords: Air pressure; temperature; height; Inquiry.

(Received July 27, 2019; Accepted September 18, 2019; Published October 24, 2019)

\begin{abstract}
ABSTRAK
Penelitian ini bertujuan untuk:1) mendeskripsikan tekanan udara tertinggi, terendah dan tekanan udara rata-rata, 2) mengetahui perbedaan hasil belajar kognitif siswa antara antara siswa yang diajar menggunakan olah data tekanan udara ekstrim dari BMKG dengan model inkuiri terhadap siswa yang diajarkan menggunakan model diskusi dan penugasan. Penelitian ini adalah penelitian eksperimen semu berdasarkan teknik Purposive Sampling dengan desain nonequivalent control group design. Sampel yang digunakan dalam penelitian ini berjumlah 2 kelas yaitu kelas VIII.1 sebagai kelas Kontrol dan kelas VIII.2 sebagai kelas ekeperimen dengan jumlah sampel dalam tiap kelas sebanyak 30 orang siswa. Instrumen yang digunakan dalam penelitian ini berupa tes objektif sebanyak 10 soal dengan empat pilihan jawaban. Hasil penelitian menunjukkan: 1) Tekanan udara dipengaruhi oleh temperature, ketinggian suatu tempat, serta sebaran lautan dan daratan. Tekanan udara tertinggi sebesar 1013,8 milibar, terendah 1004,0 milibar dan rata-rata tekanan udara sebesar 1008,6 milibar; 2) terdapat perbedaan hasil belajar kognitif antara siswa yang diajar menggunakan bahan ajar berupa olah data tekanan udara ekstrim BMKG dengan model inkuiri dengan siswa yang diajar dengan model pembelajaran diskusi dan penugasan yang ditunjukkan dengan $\mathrm{t}_{\text {hitung }}>\mathrm{t}_{\text {tabel }}(7,63>2,01)$ dengan taraf signifikasi $5 \%$.

Kata kunci: Tekanan udara; temperatur; ketinggian; model Inkuiri.
\end{abstract}




\section{PENDAHULUAN)}

Tekanan merupakan salah satu konsep dalam Fisika (IPA) yang tergolong pada konsep rumit dan sering di terapkan dalam kehidupan sehari-hari. Namun banyak siswa yang tidak memahami konsep tekanan yang salah satunya adalah tekanan udara (Bakar, 2015)

Kota bengkulu memiliki relief permukaan tanah yang bergelombang, terdiri dari pantai dan daerah perbukitan menyebabkan tekanan udara berbeda disetiap tempat sehingga juga berpengaruh terhadap suhu udara yang ekstrim. Tekanan udara ekstrim dikota bengkulu terjadi di sepanjang tahun 2012, tekanan udara pemukaan bumi merupakan salah satu unsur penting yang diamati oleh pengamat cuaca yaitu Badan Meterologi, klimatologi dan geofisika (BMKG, 2013).

Tekanan udara akan berkurang terhadap ketinggian, oleh karena itu tekanan terbesar ada pada permukaan bumi. Dengan kata lain tekanan udara adalah berat udara pada satuan luas tertentu pada suatu permukaan bumi yang dapat berubah lebih tinggi atau bahkan lebih rendah (tekanan udara ekstrim). Tekanan udara ekstrim dapat bergerak sangat cepat maupun sangat lambat, sehingga massa udara pun dapat menghangat secara intensif (Ibrahim, 2018)

Dalam beberapa proses pembelajaran terdapat kendala. Kendala-kendala yang sering terjadi dalam proses pembelajaran adalah pemilihan model yang kurang tepat, kurangnya penggunaan bahan ajar serta kondisi kelas yang berpusat pada guru. Oleh sebab itu lah diperlukan bahan ajar yang dapat membuat siswa tertarik dalam mempelajari sebuah konsep dalam pembelajaran (Vahlia, 2013).

Proses belajar yang bermutu di sekolah terdiri dari aspek pengetahuan, keterampiulan dan sikap. Tidak hanya itu ada lima komponene komunikasi di dalamnya yaitu guru, bahan ajar, siswa, tujuan pembelajaran dan media pembelajaran. Dalam hal ini bahan ajar menempati posisi yang cukup penting sebagai salah satu komponen dalam sistem pembelajaran.

Menurut (Prastowo, 2012), bahan ajar pada dasarnya merupakan segala bahan (baik informasi, alat, maupun teks) yang disusun secara sistematis, yang menampilkan sosok utuh dari kompetensi yang akan dikuasai siswa dan digunakan dalam proses pembelajaran dengan tujuan perencanaan dan penelaahan implementasi pembelajaran. Bahan ajar secara garis besar terdiri dari pengetahuan, keterampilan dan sikap yang harus dipelajari siswa dalam rangka mencapai standar kompetensi yang telah ditentukan (Depdiknas, 2006).

Salah satu upaya yang dapat dilakukan untuk meningkatkan hasil belajar serta memperbaiki kualitas pembelajaran yaitu dengan melibatkan siswa secara langsung dalam pembelajaran dan melatih siswa bersikap ilmiah melalui proses penelitian atau eksperimen agar siwa dapat memhami konsep lebih mendalam sehingga hasil belajar siswa dapat meningkat. Salah satu alternatif strategi pembelajaran IPA yang sesuai dengan kondisi tersebut yang dapat meningkatkan hasil belajar siswa adalah dengan menerapkan model pembelajaran inkuiri (Damayanti, 2014).

Menurut (Sanjaya, 2006), model pembelajaran inkuiri adalah rangkaian kegiatan pembelajaran yang menekankan pada proses berpikir secara kritis dan analitis untuk mencari dan menemukan sendiri jawaban dari suatu masalah yang dipertanyakan sehingga lebih mudah memahami ilmu dan bertahan lama. Tujuan utama pembelajaran berbasis inkuiri menurut (Julianto, 2011) adalah mengembangkan keinginan dan motivasi siswa untuk mempelajari prinsip dan konsep sains, mengembangkan keterampilan ilmiah siswa sehingga mampu bekerja seperti layaknya seorang ilmuan,membiasakan siswa bekerja keras untuk memperoleh pengetahuan.

Tahapan pada model pembelajaran inkuiri dapat dirumuskan sebagai berikut : (1) merumuskan masalah, (2)merumuskan hipotesis, (3) merancang kegiatan, (4)melakukan kegiatan, (5) mengumpulkan dan menganalisis data, dan (6) membuat kesimpulan.

Observasi yang dilakukan di SMP Negeri 4 Kota Bengkulu mendapatkan fakta bahwa hasil Ulangan Semester Ganjil Fisika Kelas VIII Tahun Pelajaran 2018/2019 cukup rendah, dengan rata-rata sebesar 60, sementara KKM sebesar 75. Rendahnya nilai siswa ini diakibatkan beberapa faktor, diantaranya kurang menariknya bahan ajar berupa buku panduan kurikulum 2013 yang tidak menyajikan gambaran tentang tekanan udara, penggunaan model pembelajaran yang kurang inovatif dan 
penggunaan media pembelajaran yang belum maksimal.

Berdasarkan hal ini, perlu dilakukan pembelajaran dengan menggunakan bahan ajar berupa olah data tekanan udara ekstrim dari BMKG dengan model pembelajaran yang dapat melibatkan siswa secara langsung dalam proses pembelajaran. Salah satu model pembelajaran yang dapat diterapkan adalah Model Pembelajaran Inkuiri.

\section{METODE PENELITIAN}

Jenis penelitian ini penelitian eksperimen semu (Quasi Eksperimental Design) karena kelompok kontrol tidak dapat berfungsi sepenuhnya untuk mengontrol variabel-variabel luar yang mempengaruhi pelaksanaan eksperimen. Penelitian kuasi eksperimen (semu) adalah penelitian yang membandingkan (komparasi) pengaruh pemberian perlakuan (tindakan) pada suatu subjek penelitian (kelompok eksperimen) serta mengukur besar pengaruh perlakuan yang telah diberikan (Sugiyono, 2010).

Pada penelitian ini kuasi eksperimen yang digunakan dengan bentuk non-equivalent control group design. Yang mana pada desain ini kelompok eksperimen maupun kelompok control tidak dipilih secara random (Sugiyono, 2010). Dimana penelitian ini dilakukan dengan tiga tahap yaitu tahap Pra Implementasi, tahap Implementasi dan tahan Pasca Implementasi.

Pada tahap pra implementasi merupakan tahap persiapan yang terdiri dari pengambilan data tekanan udara harian kota Bengkulu selama 10 tahun kemudian diolah menjadi bentuk dambar dan grafik. Selain itu dalam tahapan ini disiapkan perangkat pembelajaran berupa silabus, Rencana Pelaksanaan Pembelajaran (RPP), Lembar kerja peserta didik (LKPD) serta instrumen penelitian yang akan digunakan. Instrumen penelitian terdiri atas perangkat pembelajaran (RPP dan LKS) dan instrumen pengumpulan data (soal pretest dan posttest sebanyak 10 soal). Sebelum digunakan, semua instrumen tersebut dilakukan uji validitas. Untuk RPP dan LKS hanya dilakukan uji validitas isi oleh tiga orang, terdiri dari 1 orang Dosen Ahli dan 2 orang guru fisika. Tes kognitif dilakukan uji validitas isi dan reliabilitas (ICC) oleh tiga orang guru fisika (sebagai judgment experts). . Setelah itu, soal diujikan di lapangan. Hasil yang diperoleh digunakan untuk menguji validitas, reliabilitas, tingkat kesukaran dan daya beda soal

Tahap implmentasi merupakan tahap pelaksanaan penelitian dengan mengelompokkan siswa dalam dua kelompok belajar yaitu kelas kontrol yang diajar dengan model pembelajaran diskusi dan penugasan dan kelas eksperimen yang diajar menggunakan model pembelajaran inkuiri berbantuan olah data tekanan udara dari BMKG.

Variabel bebas dalam penelitian ini adalah olah data tekanan udara ekstrim BMKG model pembelajaran Inkuiri untuk kelas eksperimen dan pembelajaran dengan model penugasan dan diskusi untuk kelas kontrol. Sedangkan variabel terikatnya adalah hasil belajar kognitif siswa.

Tahap ketiga yaitu tahap pasca implementasi. Dimana pada tahap ini dilakukan beberapa analisa data yang diperoleh dari tahap implementasi. Rancangan penelitian (Arikunto, 2010)ditunjukkan pada Table 1 berikut ini :

Tabel 1. Desain penelitian

\begin{tabular}{|c|c|c|c|}
\hline Kelompok & Pretest & Perlakuan & Posttest \\
\hline Kontrol & $\mathrm{O}_{1}$ & $\mathrm{X}$ & $\mathrm{O}_{2}$ \\
\hline Eksperimen & $\mathrm{O}_{3}$ & $\mathrm{Y}$ & $\mathrm{O}_{4}$ \\
\hline
\end{tabular}

Keterangan:

$\mathrm{O}_{1}=$ Pretest kelas kontrol

$\mathrm{O}_{3}=$ Pretest kelas eksperimen

$\mathrm{O}_{2}=$ Posttest kelas control

$\mathrm{O}_{4}=$ Posttest kelas eksperimen

$\mathrm{X}=$ Perlakuan model pembelajaran Inkuiri

$\mathrm{Y}=$ Perlakuan model diskusi dan penugasan

Berdasarkan hasil uji tersebut diperoleh: (1) tes kognitif yang diterima 10 butir dengan realibilitas tinggi $\left(r_{11}=0,708\right)$, (2) sebanyak 5 butir soal tidak valid dan dibuang. Data penelitian ini berupa hasil belajar kognitif. Data tersebut dianalisis dengan statistik deskriptif dan statistik inferensial (Uji-t). Analisis deskriptif digunakan untuk mendeskripsikan hasil belajar kognitif siswa dari perlakuan pembelajaran. Uji-t untuk menguji hipotesis yang telah dirumuskan pada taraf signifikansi 5\%. Sebelum dilakukan uji-t, dilakukan uji prasyarat, yaitu: uji normalitas dan uji homogenitas varians. Apabila data berdistribusi normal dan varians homogen lebih kecil dari 11,07, maka uji-t dapat 
dilakukan. Hipotesis penelitian ini, yaitu: (1) terdapat peningkatan hasil belajar kognitif siswa yang diajar menggunakan olah data tekanan udara ekstrim BMKG dengan model pembelajaran Inkuiri dan siswa yang diajar menggunakan model pembelajaran diskusi dan penugasan, dan 2) terdapat perbedaan hasil belajar kognitif antara siswa yang diajar menggunakan olah data tekanan udara ekstrim BMKG dengan model pembelajaran Inkuiri dan siswa yang diajar menggunakan model pembelajaran diskusi dan penugasan . Hipotesis pertama diuji dengan nilai $\mathrm{N}_{\text {gain }}$. Hipotesis kedua diuji dengan Uji-t.

\section{HASIL DAN PEMBAHASAN}

Hasil pengambilan data temperatur udara berdasarkan waktu, ketinggian, koordinat serta kecepatan angin dapat dilihat pada Tabel 2 berikut ini:

Tabel 2. Tekanan Udara

\begin{tabular}{|c|l|c|}
\hline No & \multicolumn{1}{|c|}{ Kondisi } & $\begin{array}{c}\text { Tekanan udara } \\
\text { (milibar) }\end{array}$ \\
\hline 1 & Rata-rata & 1008,6 \\
\hline 2 & Maksimum & 1013,8 \\
\hline 3 & Minimum & 1004,0 \\
\hline
\end{tabular}

Tekanan udara rata-rata sebesar 1008,6 milibar; minimum sebesar 1004,0 milibar dan maksimum sebesar 1013,8 milibar. Tekanan udara minimum terjadi pada bulan November tahun 2009 dan tekanan udara maksimum terjadi pada bulan Juni 2015. Perbedaan tekanan udara adalah salah satu unsur cuaca yang besarnya di pengaruhi oleh beberapa factor.

Tekanan udara yang naik turun disebabkan oleh perbedaan waktu curah hujan baik di bumi bagian utara maupun bagian selatan Indonesia (Andinata, 2015). Jarak antar laut dan daratan juga dapat menjadi unsur penyebab terjadinya perubahan tekanan udara yang besar, jarak laut yang lebih dekat di bagian timur Indonesia menyebabkan fluktuasi tekanan udara lebih besar (Aldrian, 2008). Fluktuasi udara yang besar menyebabkan buruknya cuaca di Indonesia (Suryanto, 2008).

Perbedaan ini dikarenakan tekanan udara adalah salah satu cuaca yang merupakan besaran fisis terukur dan dapat menerangkan keadaaan cuaca suatu tempat. Cuaca bersifat dinamis dan sangat dipengaruhi oleh unsur-unsur cuaca lainnya seperti curah ujan, kelembaban, intensitas radiasi dan tekanan udara

Hasil pengolahan data pada lampiran 1 menunjukkan bahwa rata-rata tekanan minimum pada bulan yang berbeda dengan tahun yang sama adalah pada tahun 2009 tekanan rata-rata minimum 1006,0 milibar, pada tahun 2010 tekanan rata-rata minimum 1006,3 milibar, pada tahun 2011 tekanan rata-rata minimum 1006,2 milibar, pada tahun 2012 tekanan rata-rata minimum 1006,2 milibar, pada tahun 2013 tekanan rata-rata minimum 1006,9 milibar, pada tahun 2014 tekanan rata-rata minimum 1006,8 milibar, pada tahun 2015 tekanan rata-rata minimum 1007,9 milibar, pada tahun 2016 tekanan rata-rata minimum 1007,5 milibar, pada tahun 2017 tekanan rata-rata minimum 1007,2 milibar, dan pada tahun 2018 tekanan rata-rata minimum 1007,1 milibar.

Berdasarkan lampiran 1 rata-rata tekanan udara minimum pada bulan yang sama dengan tahun yang berbeda menunjukkan bahwa pada januari tahun 2009 - 2018 tekanan rata-rata minimum 1006,7 milibar, pada Februari tahun 2009 - 2018 tekanan rata-rata minimum 1006,5 milibar, pada maret tahun 2009 - 2018 tekanan rata-rata minimum 1007,2 milibar, pada april tahun 2012 tekanan rata-rata minimum 1006,6 milibar, pada mei tahun 2009 - 2018 tekanan rata-rata minimum 1006,2 milibar, pada juni tahun 2009 - 2018 tekanan rata-rata minimum 1006,6 milibar, pada juli tahun 2009 - 2018 tekanan rata-rata minimum 1007,1 milibar, pada agustus tahun 2009 - 2018 tekanan rata-rata minimum 1007,1 milibar, pada septemili Barer tahun 2009 - 2018 tekanan rata-rata minimum 1007,7 milibar, pada oktober tahun 2009 - 2018 tekanan rata-rata minimum 1007,0 milibar, pada November tahun 2009 - 2018 tekanan rata-rata minimum 1006,7 milibar. Dan pada Desember tahun 2009 - 2018 tekanan rata-rata minimum 1006,5 milibar.

Tekanan udara minimum terendah selama rentang tahun 2009 sampai dengan tahun 2018 terjadi pada bulan Februari tahun 2012, Oktober pada tahun 2011 dan November pada tahun 2009 sebesar 1004,0 milibar. Sedangkan tekanan udara minimum tertinggi terjadi bulan Desemili Barer tahun 2015 sebesar 1009,1 milibar. 
Winardi (2014) mengemukakan bahwa kerapatan udara dekat permukaan lebih tinggi dan lebih berkesempatan untuk menyerap radiasi panas dari permukaan bumi, maka pada siang hari suhu udara dekat permukaan akan lebih tinggi dan tekanan lebih rendah dibandingkan pada lapisan udara yang lebih tinggi. sebaliknya pada malam hari terutama saat menjelang subuh,suhu udara dekat permukaan akan menjadi lebih rendah sehingga tekanan udara menjadi lebih besar.

Hasil pengolahan data pada lampiran 2 menunjukkan bahwa rata-rata tekanan maksimum pada bulan yang berbeda dengan tahun yang sama adalah pada tahun 2009 tekanan rata-rata maksimum 1010,7 milibar, pada tahun 2010 tekanan rata-rata maksimum 1010,4 milibar, pada tahun 2011 tekanan rata-rata maksimum 1010,2 milibar, pada tahun 2012 tekanan rata-rata maksimum 1011,0 milibar, pada tahun 2013 tekanan rata-rata maksimum 1010,7 milibar, pada tahun 2014 tekanan ratarata maksimum 1011,2 milibar, pada tahun 2015 tekanan rata-rata maksimum 1012,4 milibar, pada tahun 2016 tekanan rata-rata maksimum 1011,5 milibar, pada tahun 2017 tekananratarata maksimum 1011,4 milibar, dan pada tahun 2018 tekanan rata-rata maksimum 1011,2 milibar.

Berdasarkan lampiran 2 rata-rata tekanan udara maksimum pada bulan yang sama dengan tahun yang berbeda menunjukkan bahwa pada januari tahun 2009 - 2018 tekanan rata-rata maksimum 1011,1 milibar, pada Februari tahun 2009 - 2018 tekanan rata-rata maksimum 1011,1 milibar, pada maret tahun 2009 - 2018 tekanan rata-rata maksimum 1011,3 milibar, pada april tahun 2012 tekanan rata-rata maksimum 1010,9 milibar, pada mei tahun 2009 - 2018 tekanan rata-rata maksimum 1010,4 milibar, pada juni tahun 2009 - 2018 tekanan rata-rata maksimum 1011,0 milibar, pada juli tahun 2009 - 2018 tekanan rata-rata maksimum 1011,1 milibar, pada agustus tahun 2009 - 2018 tekanan ratarata maksimum 1011,1 milibar, pada September tahun 2009 - 2018 tekanan rata-rata maksimum 1011,5 milibar, pada Oktober tahun 2009 - 2018 tekanan rata-rata maksimum 1011,6 milibar, pada November tahun 2009 - 2018 tekanan ratarata maksimum 1011,7 milibar. Dan pada
Desember tahun 2009 - 2018 tekanan rata-rata maksimum 1010,8 milibar.

Setelah pengolahan data sekunder berupa data tekanan udara ekstrim dari BMKG selesai dilaksanakan, penelitian dilanjutkan di SMP Negeri 4 Kota Bengkulu. Proses pembelajaran pada penelitian ini menggunakan olah data tekanan udara ekstrin BMKG sebagai bahan ajar dengan menerapkan model Pembelajaran Inkuiri untuk kelas eksperimen dan pembelajaran dengan model diskusi dan penugasan untuk kelas kontrol. Sebelum pembelajaran dilaksanakan kedua kelas terlebih dahulu diberi soal pretest. Nilai pretest kelas eksperimen dan kelas kontrol dapat dilihat pada gambar 1

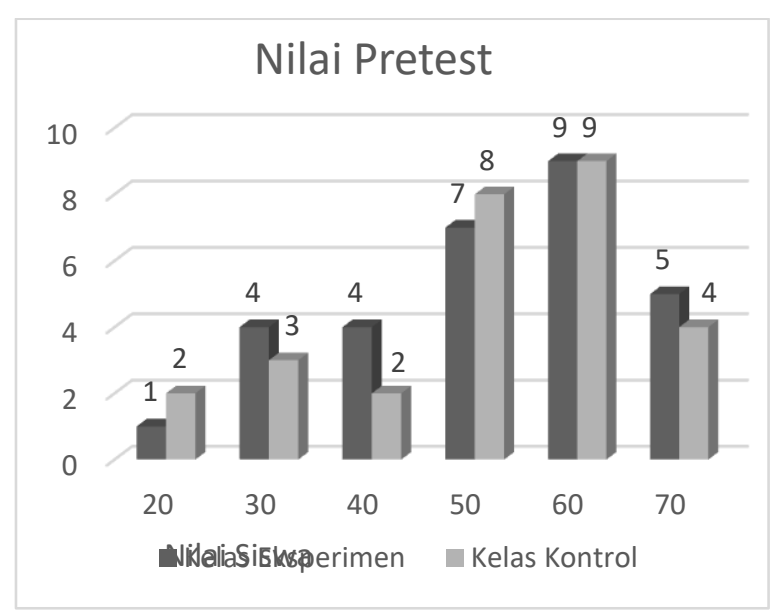

Gambar 1. Grafik Nilai Pretest Kelas Eksperimen dan Kelas Kontrol

Hasil pretest siswa dianalisis untuk membuktikan apakah kemampuan awal siswa kelas eksperimen dan kelas kontrol sama atau tidak. Analisis yang dilakukan menggunakan Uji-t, namun sebelum Uji-t dilakukan ada beberapa uji prasyarat yang dilakukan, yaitu:

1) Uji Normalitas Data Pretest

Uji normalitas data menggunakan rumus Chi Kuadrat (Chi Square). Kelas eksperimen diperoleh $\chi_{\text {hitung }}^{2}<\chi_{\text {tabel }}^{2}(2,24<11,07)$ untuk taraf signifikasi $5 \%$. Kelas kontrol diperoleh $\chi_{\text {hitung }}^{2}<\chi_{\text {tabel }}^{2}(1,25<11,07)$ untuk taraf signifikasi 5\%. Dapat disimpulkan bahwa data kelas eksperimen dan kelas kontrol, berdistribusi normal.

2) Uji Homogenitas Varians

Uji Homogenitas data pretest kedua kelompok menghasilkan $\mathrm{F}_{\text {hitung }}<\mathrm{F}_{\text {tabel }}(1,22<$ 
2,25). Sehingga dapat disimpulkan bahwa kelas eksperimen dan kelas kontrol adalah homogen.

3) Uji Hipotesis Kemampuan Awal

Uji hipotesis menggunakan Uji-t karena data kedua kelas normal dan homogen. Hasil yang diperoleh $\mathrm{t}_{\text {hitung }}<\mathrm{t}_{\text {tabel }}(0,52<2,01)$ pada taraf signifikansi 5\%. Dapat disimpulkan bahwa kemampuan awal siswa kelas eksperimen dan kelas kontrol tidak berbeda (sama). Setelah diketahui kemampuan awal siswa sama, penelitian dapat dilakukan dengan penerapan olah data tekanan udara ekstrim dengan model pembelajaran Inkuiri pada kelas eksperimen dan pembelajaran dengan model diskusi dan penugasan pada kelas kontrol. Setelah pembelajaran selesai, diberikan soal posttest untuk mengukur kemampuan akhir siswa. Nilai posttest kelas eksperimen dan kelas kontrol disajikan dalam gambar 2 berikut ini:

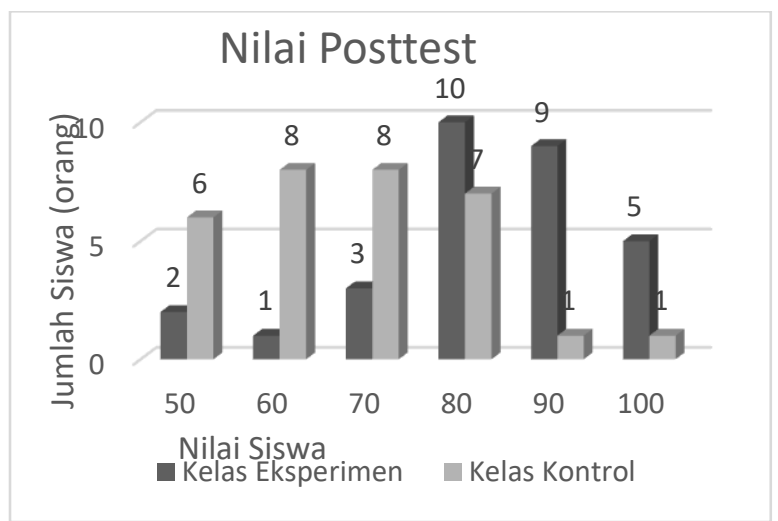

Gambar 2. Grafik Nilai Posttest Kelas Eksperimen dan Kelas Kontrol

Hasil posttest siswa dianalisis untuk membuktikan apakah kemampuan akhir siswa kelas eksperimen dan kelas kontrol sama atau tidak. Analisis yang dilakukan menggunakan Uji-t, namun sebelum Uji-t dilakukan ada beberapa uji prasyarat yang dilakukan, yaitu:

1) Uji Normalitas Data Posttest

Uji normalitas data menggunakan rumus Chi Kuadrat (Chi Square). Kelas eksperimen diperoleh $\chi_{\text {hitung }}^{2}<\chi_{\text {tabel }}^{2}(2,235<11,07)$ untuk taraf signifikasi 5\%. Kelas kontrol diperoleh $\chi_{\text {hitung }}^{2}<\chi_{\text {tabel }}^{2}(1,25<11,07)$ untuk taraf signifikasi $5 \%$. Dapat disimpulkan bahwa data kelas eksperimen dan kelas kontrol, berdistribusi normal.

2) Uji Homogenitas Varians
Uji Homogenitas data pretest kedua kelompok menghasilkan $\mathrm{F}_{\text {hitung }}<\mathrm{F}_{\text {tabel }}(1,19<$ 4,04). Sehingga dapat disimpulkan bahwa kelas eksperimen dan kelas kontrol adalah homogen.

3) Uji Hipotesis Kemampuan Akhir

Uji hipotesis menggunakan Uji-t karena data kedua kelas normal dan homogen. Hasil yang diperoleh $t_{\text {hitung }}>t_{\text {tabel }}(7,63>2,01)$ pada taraf signifikansi 5\%. Dapat disimpulkan bahwa kemampuan akhir siswa kelas dan kelas kontrol berbeda.

Dari hasil uji hipotesis Kemampuan akhir siswa diketahui bahwa terdapat perbedaan hasil tes akhir siswa antara kelas eksperimen dan kelas kontrol. Hal ini dikarenakan adanya perbedaan perlakuan pada dua kelompok tersebut. Perlakuan tersebut berupa penerapan olah data tekanan udara ekstrim sebagai bahan ajar dengan model Inkuiri pada kelas eksperimen dan pembelajaran dengan model diskusi dan penugasan pada kelas kontrol. Berdasarkan nilai pretest dan posttest kelas eksperimen dan kelas kontrol, diketahui bahwa baik kelas kontrol ataupun kelas eksperimen pada dasarnya mengalami peningkatan hasil belajar. Kelas eksperimen mengalami peningkatan hasil belajar $\left(\mathrm{N}_{\text {-gain }}\right)$ yang lebih tinggi yakni sebesar 0,73 (tinggi) daripada siswa kelas kontrol sebesar 0,31 (sedang). Dapat disimpulkan bahwa penerapan olah data tekanan udara ekstrim BMKG dengan model pembelajaran Inkuiri lebih dapat meningkatkan hasil belajar fisika siswa daripada pembelajarandengan model diskusi dan penugasan.

Peningkatan hasil belajar fisika yang dicapai oleh siswa tentunya tidak terlepas dari beberapa faktor pendukung, baik yang bersifat internal maupun yang bersifat eksternal. Faktor internal yang turut serta berperan dalam meningkatkan hasil belajar kognitif siswa yaitu berupa kemampuan-kemampuan yang terdapat dalam diri siswa, salah satunya adalah kemampuan untuk menguasai aturan-aturan atau langkah-langkah yang diperlukan dalam proses sains itu sendiri. Sedangkan faktor eksternal yang turut mendukung peningkatan kemampuan pemahaman serta prestasi belajar fisika pada siswa salah satunya adalah dengan penerapan model pembelajaran Inkuiri dalam kegiatan pembelajaran (Munnawaroh, 2009). 


\section{KESIMPULAN}

Tekanan udara dipengaruhi oleh ketinggian suatu tempat, temperatur dan sebaran lautan dan daratan. Tekanan udara tertinggi sebesar 1013,8 milibar, terendah sebesar 1004,0 milibar dan rata-rata sebesar 1008,6 milibar. Terdapat perbedaan hasil belajar kognitif antara siswa yang diajar dengan olah data tekanan udara ekstrim BMKG dengan model pembelajaan Inkuiri dengan siswa diajar dengan model diskusi dan penugasan yang ditunjukkan dengan $t_{\text {hitung }}>t_{\text {tabel }}(7,63>2,01)$ pada taraf signifikasi $5 \%$..

\section{DAFTAR PUSTAKA}

Abu Bakar, A. H. (2015). Penerapan Pendekatan Keterampilan Proses Sains dan Penguasaan Konsep Siswa SMPPada Konsep Tekanan. Jurnal Pendidikan Sains Indonesia Vol 03 No.01, 1-6.

Andinata, P. S. (2015). Pola Spasial dan Temporal Klimatologis Tekanan Udara Permukaan Wilayah Indonesia. Bogor: Institut Pertanian Bogor.

Aldrian. (2008). Meteorologi Laut Indonesia. Jakartao: Badan Meteorologi dan Geofisika.

Arikunto. (2010). Dasar-dasar Evaluasi Pendidikan. Jakarta: Rineka Cipta.

Damayanti, I. (2014). Penerapan Model Pembelajaran Inkuiri untuk Meningkatkan Hasil Belajar Mata Pelajaran IPA Sekolah Dasar. Jurnal Pendidikan JPGSD Vol. 02 No. 03.

Depdiknas. (2006). Bahan Ajar. Jakarta: Depdiknas.

Ibrahim, F. M. (2018). Australia: ABC.

Julianto. (2011). Teori dan Implementasi Modelmodel Pembelajaran Inovatif. Surabaya: UNESA.

Munnawaroh. (2009). Pengaruh Pembelajaran Inkuiri Terbimbing Terhadap Hasil Belajar Fisika Siswa.

Prastowo. (2012). Lampung: Universitas Lampung.

Sanjaya, W. (2006). Strategi Pembelajaran Berorientasi Standar Proses Pendidikan. Jakarta: Kencana.

Suryanto. (2008). Siklus Tropis di Selatan dan Barat Daya Indonesia dari Pemantauan
Satelit TRMM dan Kemungkinan Kaitannya dengan Gelombang Tinggi dan Puting Beliung. Jakarta: Sains dan Teknologi Dirgantara.

Vahlia. (2013). Eksperimental Model Pembelajaran Discovery dan Group Investigasi terhadap Prestasi Belajar Matematika Ditinjau dari Kreativitas Siswa. Jurnal Universitas Sebelas Maret. 